National Water Quality Program

National Water-Quality Assessment Project

\title{
Potential Corrosivity of Untreated Groundwater in the United States
}

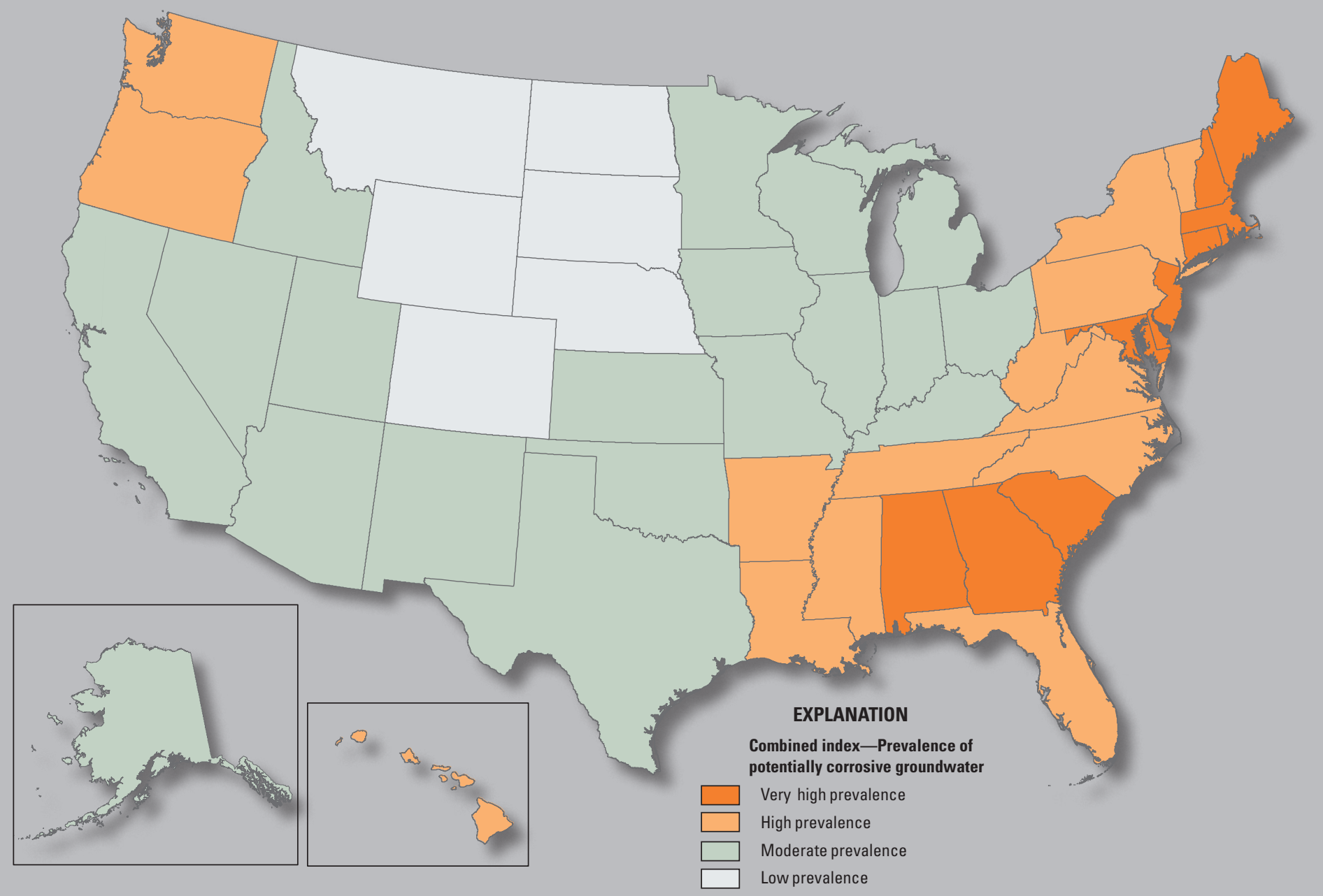

Scientific Investigations Report 2016-5092

U.S. Department of the Interior

U.S. Geological Survey 
Cover. Map showing the prevalence of potentially corrosive groundwater for the 50 states and the District of Columbia (fig. 6, p. 11). 


\section{Potential Corrosivity of Untreated Groundwater in the United States}

By Kenneth Belitz, Bryant C. Jurgens, and Tyler D. Johnson

National Water Quality Program

National Water-Quality Assessment Project

Scientific Investigations Report 2016-5092 


\title{
U.S. Department of the Interior SALLY JEWELL, Secretary
}

\section{U.S. Geological Survey Suzette M. Kimball, Director}

\author{
U.S. Geological Survey, Reston, Virginia: 2016
}

For more information on the USGS - the Federal source for science about the Earth, its natural and living resources, natural hazards, and the environment—visit http://www.usgs.gov or call 1-888-ASK-USGS.

For an overview of USGS information products, including maps, imagery, and publications, visit http://www.usgs.gov/pubprod/.

Any use of trade, firm, or product names is for descriptive purposes only and does not imply endorsement by the U.S. Government.

Although this information product, for the most part, is in the public domain, it also may contain copyrighted materials as noted in the text. Permission to reproduce copyrighted items must be secured from the copyright owner.

Suggested citation:

Belitz, Kenneth, Jurgens, B.C., and Johnson, T.D., 2016, Potential corrosivity of untreated groundwater in the United States: U.S. Geological Survey Scientific Investigations Report 2016-5092, 16 p.,

http://dx.doi.org/10.3133/sir20165092

ISSN 2328-0328 (online) 


\section{Contents}

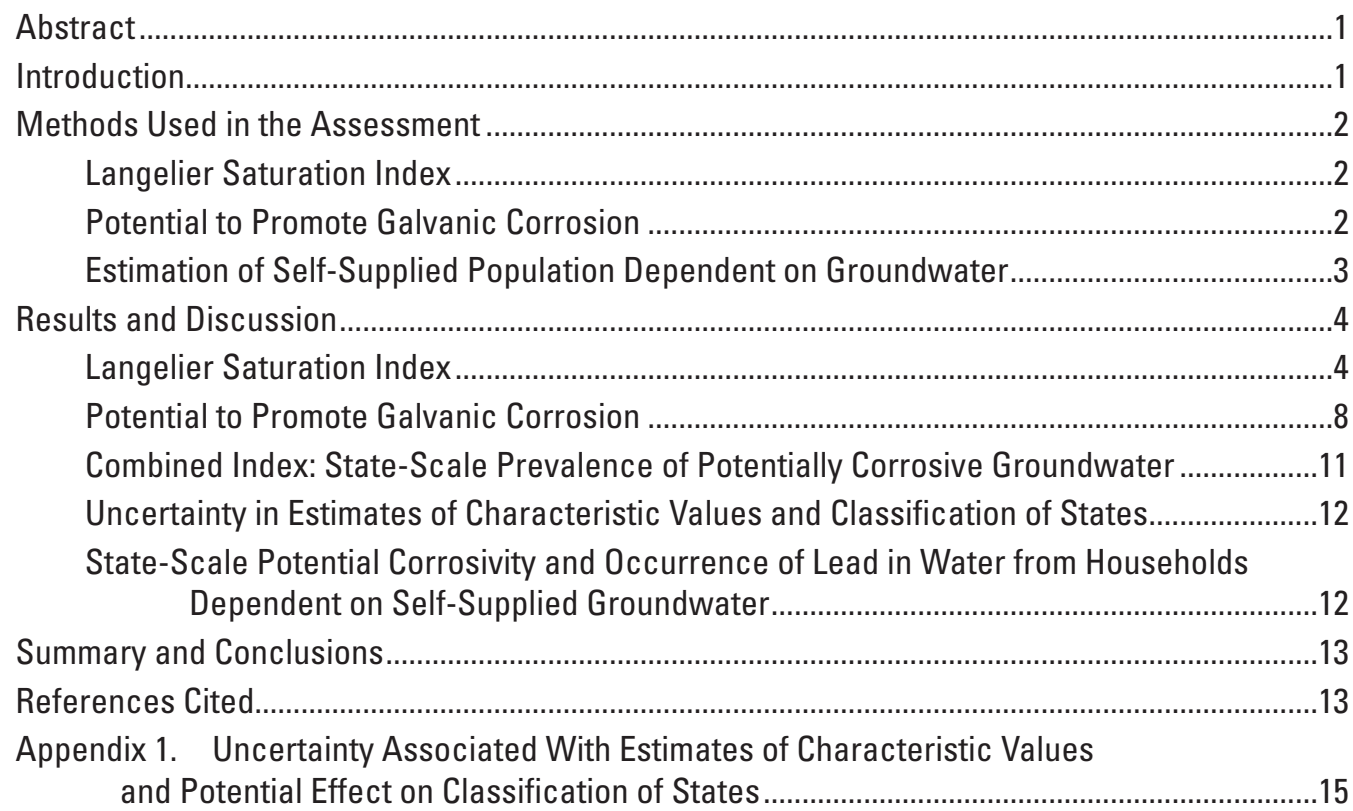

\section{Figures}

1. Map of the United States showing the Langelier Saturation Index for 20,962 groundwater sites.

2. Map showing pie charts and classifications based on Langelier Saturation Index for the 50 states and the District of Columbia.

3. Map of the United States showing Potential to Promote Galvanic Corrosion for 26,631 groundwater sites.

4. Map showing pie charts and classifications based on Potential to Promote Galvanic Corrosion for the 50 states and the District of Columbia.

5. Classification system for identifying the state-scale prevalence of potentially corrosive groundwater

6. Map showing the prevalence of potentially corrosive groundwater for the 50 states and the District of Columbia 


\section{Tables}

1. Chemical constituents and parameter codes used in computations of the Langelier Saturation Index and the Potential to Promote Galvanic Corrosion .3

2. Summary of the population dependent on self-supplied groundwater, the number of wells available for evaluating the Langelier Saturation Index and Potential to Promote Galvanic Corrosion, and the classification of state-scale prevalence of potentially corrosive groundwater for the 50 states and the District of Columbia .......5

3. Summary of the characteristic values, and the uncertainty in those values, of the Langelier Saturation Index for the 50 states and the District of Columbia

4. Summary of the characteristic values, and the uncertainty in those values, of the Potential to Promote Galvanic Corrosion for the 50 states and the District of Columbia

5. Summary of the surveys of lead detection frequency in samples from households dependent on self-supplied groundwater.

\section{Supplemental Information}

Specific conductance is given in microsiemens per centimeter at 25 degrees Celsius $\left(\mu \mathrm{S} / \mathrm{cm}\right.$ at $\left.25^{\circ} \mathrm{C}\right)$.

Concentrations of chemical constituents in water are given in either milligrams per liter (mg/L) or micrograms per liter $(\mu \mathrm{g} / \mathrm{L})$.

\section{Abbreviations}

$\mathrm{Cl}$

combined index

CSMR

chloride-to-sulfate mass ratio

EPA

U.S. Environmental Protection Agency

LSI Langelier Saturation Index

NWIS National Water Information System

PPGC Potential to Promote Galvanic Corrosion

SC specific conductance

TDS total dissolved solids

USGS U.S. Geological Survey 


\title{
Potential Corrosivity of Untreated Groundwater in the United States
}

\author{
By Kenneth Belitz, Bryant C. Jurgens, and Tyler D. Johnson
}

\section{Abstract}

Corrosive groundwater, if untreated, can dissolve lead and other metals from pipes and other components in water distribution systems. Two indicators of potential corrosivity - the Langelier Saturation Index (LSI) and the Potential to Promote Galvanic Corrosion (PPGC) - were used to identify which areas in the United States might be more susceptible to elevated concentrations of metals in household drinking water and which areas might be less susceptible. On the basis of the LSI, about one-third of the samples collected from about 21,000 groundwater sites are classified as potentially corrosive. On the basis of the PPGC, about two-thirds of the samples collected from about 27,000 groundwater sites are classified as moderate PPGC, and about one-tenth as high PPGC. Potentially corrosive groundwater occurs in all 50 states and the District of Columbia.

National maps have been prepared to identify the occurrence of potentially corrosive groundwater in the 50 states and the District of Columbia. Eleven states and the District of Columbia were classified as having a very high prevalence of potentially corrosive groundwater, 14 states as having a high prevalence of potentially corrosive groundwater, 19 states as having a moderate prevalence of potentially corrosive groundwater, and 6 states as having a low prevalence of potentially corrosive groundwater. These findings have the greatest implication for people dependent on untreated groundwater for drinking water, such as the 44 million people that are self-supplied and depend on domestic wells or springs for their water supply.

\section{Introduction}

Corrosive water, if untreated, can dissolve lead and other metals from pipes and other components in water distribution systems (Gregory, 1985; Edwards and Triantafyllidou, 2007; Swistock and others, 2009; Pieper and others, 2015). In the United States, water used for public supply is regulated and often is treated to control corrosion, metal contamination, and other undesirable qualities (U.S. Environmental Protection Agency, 2016). In contrast, self-supplied water is not generally regulated and often is not treated. Nationally, about 44 million people rely on self-supplied water, with groundwater accounting for about 98 percent of that supply (Maupin and others, 2014). Self-supplied groundwater typically is obtained from domestic wells, but sometimes is obtained from springs. In addition, groundwater provides about 37 percent of the water provided for public supply (Maupin and others, 2014). Given the importance of groundwater as a source of drinking water, particularly in self-supplied households, an assessment of the potential corrosivity of untreated groundwater in the United States was conducted by the U.S. Geological Survey (USGS) as part of the National Water-Quality Assessment project (NAWQA). NAWQA is a part of the National Water Quality Program.

The corrosivity of water is one of many factors that can affect the occurrence of lead and other metals in household water supplies (U.S. Environmental Protection Agency, 2016). Although several different indicators have been developed to quantify the corrosivity of water (Singley and others, 1984; Roberge, 2007), the results presented in this report are based on two such indicators. The two indicators were selected to provide a national characterization of the potential corrosivity of untreated groundwater.

The first indicator used to quantify the potential corrosivity of water is the Langelier Saturation Index (LSI) (Langelier, 1936; Larson and others, 1942). The LSI provides an indication of the extent to which calcium carbonate scale might be deposited inside pipes and other components of a distribution system. In the absence of a protective scale, lead, if present, may dissolve into the water (Langelier, 1936; Stumm and Morgan, 1981; Hu and others, 2012). In addition, if scaling does occur, any lead that is present might be sequestered in the scale as lead carbonate (Garrels and Christ, 1965). The LSI only indicates the tendency for scaling to occur; it is not a measurement of corrosivity (Singley and others, 1984).

The second indicator used to quantify the potential corrosivity of water is a three-tier classification system developed by Nguyen and others $(2010,2011)$ to assess levels of concern related to galvanic corrosion of lead in water distribution systems. The indicator is referred to as the Potential to Promote Galvanic Corrosion (PPGC). Galvanic corrosion of lead is an electrochemical process that can occur when lead pipe or lead solder is in contact with a dissimilar metal such as copper. If the source water entering a system has a relatively 
elevated chloride-to-sulfate mass ratio (CSMR), the potential for galvanic corrosion to occur is elevated (Gregory 1985; Edwards and Triantafyllidou, 2007; Hu and others, 2012), especially in water with low values of alkalinity (Nguyen and others, 2011).

The purpose of this report is to present national maps of the distribution of two indicators of the potential corrosivity of untreated groundwater across the Nation - the LSI and PPGC (Belitz and others, 2016a, b). For each indicator, two national maps are presented. The first map shows the values of the indicator at individual groundwater sites. The second map shows for each state a pie chart illustrating the distribution of the values of the indicator within that state and a classification of the potential corrosivity of groundwater for that state. The second map is referred to as a state-scale map. A fifth map, based on a combination of the two state-scale maps, shows the prevalence of potentially corrosive groundwater for each of the states and the District of Columbia. The maps are based on data collected at about 27,000 groundwater sites and obtained from the USGS National Water Information System (NWIS).

\section{Methods Used in the Assessment}

\section{Langelier Saturation Index}

The LSI is an indicator of the potential for calcium carbonate $\left(\mathrm{CaCO}_{3}\right.$ or the mineral calcite) to form a scale and is computed as the difference between the measured $\mathrm{pH}$ of the water and the $\mathrm{pH}$ at calcite saturation $\left(\mathrm{pH}_{\mathrm{s}}\right)($ Langelier, 1936; Larson and others, 1942):

$$
\mathrm{LSI}=\mathrm{pH}-\mathrm{pH}_{\mathrm{s}}
$$

The derivation of $\mathrm{pH}_{\mathrm{s}}$ is based on carbonate equilibria, the effects of temperature on the equilibrium constants, and the effects of salinity on chemical activities. Roberge (2007) provided a simple expression for approximating the relations presented by Larson and others (1942). The $\mathrm{pH}_{\mathrm{s}}$ is computed from alkalinity (milligrams per liter as $\mathrm{CaCO}_{3}$ ), calcium concentration (milligrams per liter calcium ions $\left[\mathrm{Ca}^{2+}\right]$ as $\mathrm{CaCO}_{3}$ ), total dissolved solids (TDS; milligrams per liter), and water temperature (degrees Celsius, ${ }^{\circ} \mathrm{C}$ ) (Roberge, 2007):

$$
\mathrm{pH}_{\mathrm{s}}=(9.3+A+B)-(C+D)
$$

where

$$
\begin{array}{ll}
A= & \left(\log _{10}[\mathrm{TDS}]-1\right) / 10, \\
B= & -13.12 \times \log _{10}\left({ }^{\circ} \mathrm{C}+273\right)+34.55, \\
C= & \log _{10}\left[\mathrm{Ca}^{2+} \text { as } \mathrm{CaCO}_{3}\right]-0.4, \text { and } \\
D= & \log _{10}\left[\text { alkalinity as } \mathrm{CaCO}_{3}\right] .
\end{array}
$$

Theoretically, negative values of LSI indicate that calcium carbonate scale is not likely to form, and positive values indicate conditions are favorable to scale formation (Langelier, 1936). Values close to zero can be considered borderline (Roberge, 2007). For the purposes of this assessment, LSI values less than -0.5 were classified as potentially corrosive, LSI values greater than or equal to -0.5 and less than or equal to 0.5 were classified as indeterminate, and LSI values greater than 0.5 were classified as scale forming (Langland and Dugas, 1996).

The LSI was computed for groundwater samples collected from 20,962 sites in the United States (Belitz and others, 2016a). The sites included domestic wells, public supply wells, wells of other types, and springs. The data for the computations of LSI were obtained from NWIS. At each site, the most recent sample (during the period 1991-2015) with the necessary water-quality measurements for computing the LSI (table 1) was retained. Where multiple alkalinity values were available for a site, a single value was chosen on the basis of availability in the following NWIS parameter code order: 39086, 39036, and 29802. Where TDS was not measured, TDS was estimated from specific conductance (SC) values by multiplying SC by a factor of 0.69 (Hem, 1985). For some groundwater samples, laboratory values of $\mathrm{pH}$ (00403), alkalinity (29801), and specific conductance (90095) were used when field values were not available.

Characteristic statewide values of LSI were computed for the 50 states and for the District of Columbia. For each state and the District of Columbia, four characteristic values were computed (Belitz and others, 2016a): average LSI, proportion of sites that are classified as potentially corrosive, proportion of sites that are classified as indeterminate, and proportion of sites that are classified as scale forming. States were classified as potentially corrosive if the average LSI was less than -0.5 , indeterminate if the average LSI was greater than or equal to -0.5 and less than or equal to 0.5 , and scale forming if the average LSI was greater than 0.5 . The uncertainty associated with the estimate of the average LSI for a state was computed using the standard confidence interval at a 90-percent confidence level (Ott and Longnecker, 2001). Additional information on confidence intervals is presented in appendix 1.

\section{Potential to Promote Galvanic Corrosion}

Nguyen and others (2011) developed a decision tree to help utilities evaluate treatment alternatives that might cause galvanic corrosion of lead. Three levels of concern were defined on the basis of the CSMR (with concentrations expressed as milligrams per liter) and alkalinity (milligrams per liter as $\mathrm{CaCO}_{3}$ ): no concern, significant concern, and serious concern. Nguyen and others (2011) noted that if there is no lead present in the system or if there are no partially replaced lead components, then the classification is "no concern." In this report, untreated groundwater was assessed and the three-tier classification system was applied without 
Table 1. Chemical constituents and parameter codes used in computations of the Langelier Saturation Index (LSI) and the Potential to Promote Galvanic Corrosion (PPGC).

[Parameter codes are defined in the U.S. Geological Survey National Water Information System, http://nwis.waterdata.usgs.gov/nwis]

\begin{tabular}{|c|c|c|c|}
\hline $\begin{array}{c}\text { Parameter } \\
\text { code }\end{array}$ & LSI & PPGC & Description \\
\hline 00095 & $\mathrm{x}$ & & Specific conductance, water, unfiltered, microsiemens per centimeter at 25 degrees Celsius \\
\hline 90095 & $\mathrm{x}$ & & Specific conductance, water, unfiltered, laboratory, microsiemens per centimeter at 25 degrees Celsius \\
\hline 00400 & $\mathrm{x}$ & & $\mathrm{pH}$, water, unfiltered, field, standard units \\
\hline 00403 & $\mathrm{x}$ & & $\mathrm{pH}$, water, unfiltered, laboratory, standard units \\
\hline 00915 & $\mathrm{x}$ & & Calcium, water, filtered, milligrams per liter \\
\hline 00940 & & $\mathrm{x}$ & Chloride, water, filtered, milligrams per liter \\
\hline 00945 & & $\mathrm{x}$ & Sulfate, water, filtered, milligrams per liter \\
\hline 29801 & $\mathrm{x}$ & $\mathrm{X}$ & Alkalinity, water, filtered, fixed endpoint ( $\mathrm{pH} 4.5$ ) titration, laboratory, milligrams per liter as calcium carbonate \\
\hline 29802 & $\mathrm{x}$ & $\mathrm{x}$ & Alkalinity, water, filtered, Gran titration, field, milligrams per liter as calcium carbonate \\
\hline 39036 & $\mathrm{x}$ & $\mathrm{x}$ & Alkalinity, water, filtered, fixed endpoint ( $\mathrm{pH} 4.5)$ titration, field, milligrams per liter as calcium carbonate \\
\hline 39086 & $\mathrm{x}$ & $\mathrm{x}$ & Alkalinity, water, filtered, incremental titration, field, milligrams per liter as calcium carbonate \\
\hline 70300 & $\mathrm{x}$ & & Residue on evaporation, dried at 180 degrees Celsius, water, filtered, milligrams per liter \\
\hline
\end{tabular}

considering the absence or presence of lead in the distribution system. Consequently, the three-tier classification system is referred to in this report as the Potential to Promote Galvanic Corrosion (PPGC), and the three levels of concern are redefined as low, moderate, and high PPGC: If CSMR $<0.2$, then PPGC is low; if $0.2<=$ CSMR $<=0.5$, then PPGC is moderate; if CSMR $>0.5$ and alkalinity $>=50$, then PPGC is moderate; and if CSMR $>0.5$ and alkalinity $<50$, then PPGC is high.

The PPGC was computed for samples collected from 26,631 groundwater sites in the United States (Belitz and others, 2016b). The sites included domestic wells, public supply wells, wells of other types, and springs. The data for the computations of PPGC were obtained from NWIS. At each site, the most recent sample (during the period 1991-2015) with the necessary water-quality measurements for computing the PPGC (table 1) was retained. Where multiple alkalinity values were available for a site, a single value was chosen on the basis of availability in the following NWIS parameter code order: 39086, 39036, and 29802. For some groundwater samples, laboratory values of alkalinity (29801) were used when a field value was not available.

Characteristic statewide values of PPGC were computed for the 50 states and the District of Columbia (Belitz and others, 2016b). For each state and the District of Columbia, four characteristic values were computed: proportion of sites where PPGC is low, proportion of sites where PPGC is moderate, proportion of sites where PPGC is high, and a statewide category. A state was classified as low if more than 50 percent of the sites in the state were classified as low. If a state was not classified as low, it was classified as moderate if 25 percent or less of the sites were classified as high. A state was classified as high if it was not classified as low and if more than 25 percent of the sites were classified as high. The uncertainty associated with estimating the proportion of groundwater sites with a given classification was computed using the Clopper-Pearson interval (Clopper and Pearson, 1934; Brown and others, 2001) at a 90-percent confidence level. The Clopper-Pearson interval is often referred to as the exact method. Additional information on computation of confidence intervals is presented in appendix 1 .

\section{Estimation of Self-Supplied Population Dependent on Groundwater}

Maupin and others (2014) provided state-scale estimates of the self-supplied population and the volumes of self-supplied water derived from groundwater and surfacewater sources. In this report, the population dependent on self-supplied groundwater was estimated by multiplying the self-supplied population by the fraction of the self-supplied volume that is provided by groundwater. 


\section{Results and Discussion}

\section{Langelier Saturation Index}

The LSI was mapped at a national scale by using data from 20,962 groundwater sites (fig. 1; table 2). Nationally, 32 percent of the groundwater sites were classified as potentially corrosive, 63 percent as indeterminate, and 5 percent as scale forming (Belitz and others, 2016a). States were classified on the basis of the average LSI of the groundwater sites located within the state (fig. 2; table 3): 25 states and the District of Columbia were classified as potentially corrosive, and 25 states were classified as indeterminate. No states were classified as scale forming with respect to LSI. The population dependent on self-supplied groundwater in the 25 states classified as potentially corrosive with respect to LSI is 24 million people (table 2).
Potentially corrosive groundwater occurs in every state; the states with the largest percentages of sites classified as potentially corrosive are located in the Northeast, the mid-Atlantic, the Southeast, and the Pacific Northwest (fig. 2; table 3). Hawaii also has a relatively large percentage of groundwater sites classified as potentially corrosive.

The LSI classification of indeterminate includes groundwater sites that could be considered borderline potentially corrosive ( -0.5 to 0 ) and sites that could be considered borderline scale forming ( 0 to 0.5$)$. The indeterminate class accounts for about two-thirds of all groundwater sites, with the number of borderline potentially corrosive sites about equal to the number of borderline scale forming sites (Belitz and others, 2016a). The average LSI is indeterminate in 25 states-borderline potentially corrosive in 18 and borderline scale forming in 7 (table 3 ).

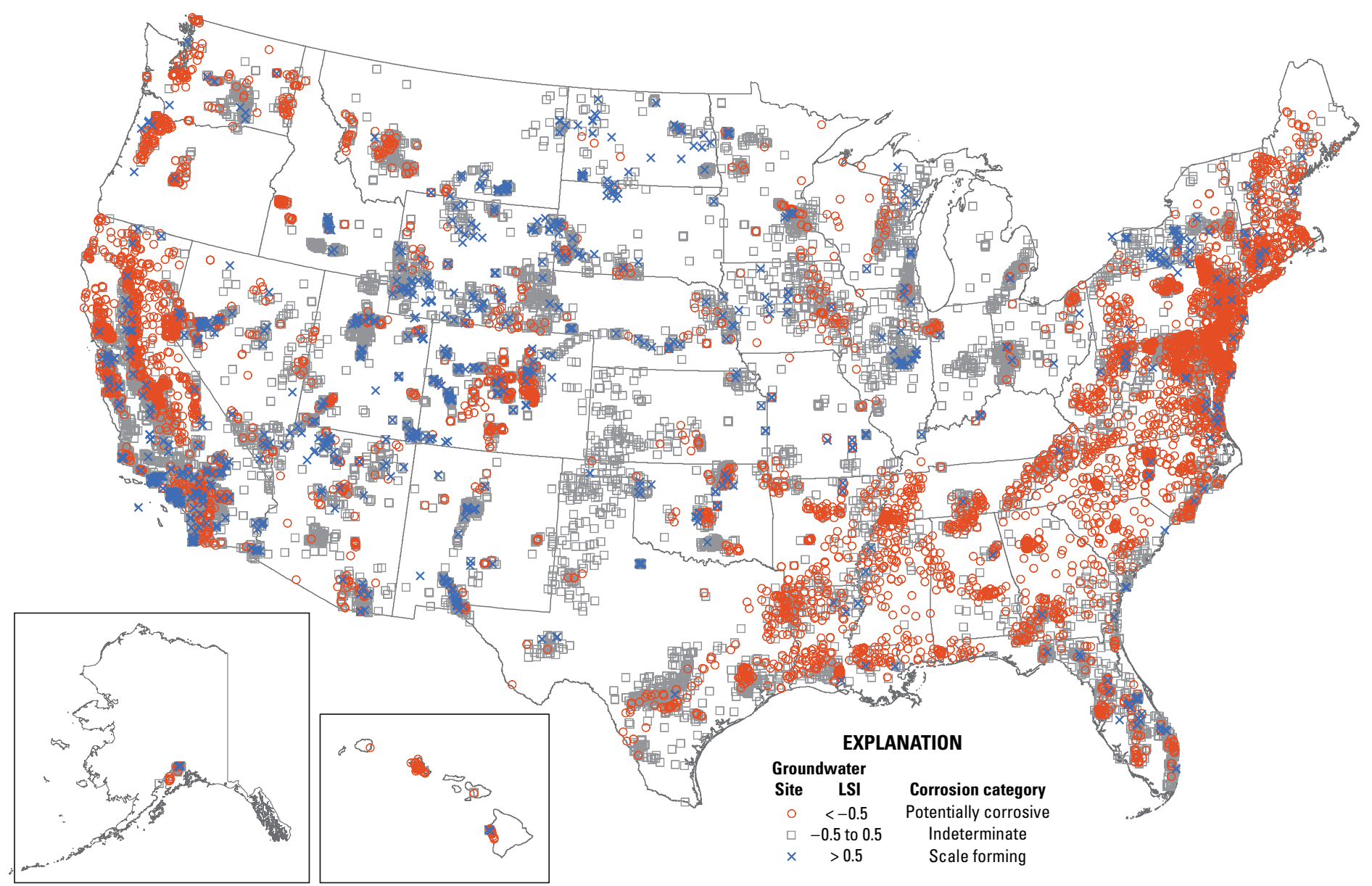

Figure 1. The Langelier Saturation Index for 20,962 groundwater sites in the United States. LSI, Langelier Saturation Index. 
Table 2. Summary of the population dependent on self-supplied groundwater, the number of wells available for evaluating the Langelier Saturation Index (LSI) and Potential to Promote Galvanic Corrosion (PPGC), and the classification of state-scale prevalence of potentially corrosive groundwater for the 50 states and the District of Columbia.

\begin{tabular}{|c|c|c|c|c|c|}
\hline \multirow{2}{*}{ State name } & \multirow{2}{*}{$\begin{array}{l}\text { Population dependent } \\
\text { on domestic wells }\end{array}$} & \multicolumn{2}{|c|}{ Number of available wells } & \multicolumn{2}{|c|}{ Classification } \\
\hline & & LSI & PPGC & LSI & PPGC \\
\hline \multicolumn{6}{|c|}{ States classified as Very High Prevalence of Potentially Corrosive Groundwater } \\
\hline Alabama & 539,000 & 203 & 210 & Potentially Corrosive & High \\
\hline Connecticut & 871,000 & 194 & 195 & Potentially Corrosive & High \\
\hline Delaware & 185,000 & 253 & 302 & Potentially Corrosive & High \\
\hline District of Columbia & 0 & 30 & 28 & Potentially Corrosive & High \\
\hline Georgia & $1,530,000$ & 326 & 402 & Potentially Corrosive & High \\
\hline Maine & 561,000 & 86 & 86 & Potentially Corrosive & High \\
\hline Maryland & $1,070,000$ & 528 & 629 & Potentially Corrosive & High \\
\hline Massachusetts & 534,000 & 121 & 129 & Potentially Corrosive & High \\
\hline New Hampshire & 446,000 & 75 & 97 & Potentially Corrosive & High \\
\hline New Jersey & 964,000 & 542 & 739 & Potentially Corrosive & High \\
\hline Rhode Island & 113,000 & 6 & 6 & Potentially Corrosive & High \\
\hline South Carolina & $1,150,000$ & 158 & 183 & Potentially Corrosive & High \\
\hline \multicolumn{6}{|c|}{ States classified as High Prevalence of Potentially Corrosive Groundwater } \\
\hline Arkansas & 144,000 & 202 & 246 & Potentially Corrosive & Moderate \\
\hline Florida & $1,910,000$ & 887 & 1,093 & Potentially Corrosive & Moderate \\
\hline Hawaii & 13,000 & 68 & 70 & Potentially Corrosive & Moderate \\
\hline Louisiana & 588,000 & 373 & 398 & Potentially Corrosive & Moderate \\
\hline Mississippi & 446,000 & 152 & 181 & Potentially Corrosive & Moderate \\
\hline New York & $2,050,000$ & 401 & 422 & Potentially Corrosive & Moderate \\
\hline North Carolina & $3,300,000$ & 564 & 581 & Potentially Corrosive & Moderate \\
\hline Oregon & 543,000 & 206 & 198 & Potentially Corrosive & Moderate \\
\hline Pennsylvania & $3,350,000$ & 396 & 657 & Potentially Corrosive & Moderate \\
\hline Tennessee & 538,000 & 286 & 431 & Potentially Corrosive & Moderate \\
\hline Vermont & 182,000 & 35 & 35 & Potentially Corrosive & Moderate \\
\hline Virginia & $1,650,000$ & 629 & 639 & Potentially Corrosive & Moderate \\
\hline Washington & $1,000,000$ & 372 & 424 & Potentially Corrosive & Moderate \\
\hline West Virginia & 385,000 & 292 & 573 & Potentially Corrosive & Moderate \\
\hline \multicolumn{6}{|c|}{ States classified as Moderate Prevalence of Potentially Corrosive Groundwater } \\
\hline Alaska & 248,000 & 58 & 52 & Indeterminate & Moderate \\
\hline Arizona & 218,000 & 672 & 967 & Indeterminate & Moderate \\
\hline California & $2,053,000$ & 4,280 & 4,495 & Indeterminate & Moderate \\
\hline Idaho & 432,000 & 178 & 1,615 & Indeterminate & Moderate \\
\hline Illinois & $1,160,000$ & 267 & 254 & Indeterminate & Moderate \\
\hline Indiana & $1,660,000$ & 111 & 207 & Indeterminate & Moderate \\
\hline Iowa & 591,000 & 347 & 573 & Indeterminate & Moderate \\
\hline Kansas & 151,000 & 205 & 330 & Indeterminate & Moderate \\
\hline Kentucky & 394,000 & 15 & 32 & Indeterminate & Moderate \\
\hline Michigan & $2,680,000$ & 164 & 192 & Indeterminate & Moderate \\
\hline Minnesota & $1,130,000$ & 379 & 399 & Indeterminate & Moderate \\
\hline Missouri & 883,000 & 177 & 356 & Indeterminate & Moderate \\
\hline Nevada & 158,000 & 866 & 923 & Indeterminate & Moderate \\
\hline New Mexico & 303,000 & 446 & 492 & Indeterminate & Moderate \\
\hline Ohio & $1,793,000$ & 328 & 444 & Indeterminate & Moderate \\
\hline Oklahoma & 316,000 & 403 & 396 & Indeterminate & Moderate \\
\hline Texas & $2,440,000$ & 1,079 & 1,125 & Indeterminate & Moderate \\
\hline Utah & 51,000 & 660 & 846 & Indeterminate & Moderate \\
\hline Wisconsin & $1,640,000$ & 232 & 265 & Indeterminate & Moderate \\
\hline \multicolumn{6}{|c|}{ States classified as Low Prevalence of Potentially Corrosive Groundwater } \\
\hline Colorado & 312,000 & 915 & 1,221 & Indeterminate & Low \\
\hline Montana & 272,000 & 374 & 429 & Indeterminate & Low \\
\hline Nebraska & 346,000 & 355 & 713 & Indeterminate & Low \\
\hline North Dakota & 49,000 & 175 & 368 & Indeterminate & Low \\
\hline South Dakota & 76,000 & 246 & 319 & Indeterminate & Low \\
\hline Wyoming & 114,000 & 645 & 664 & Indeterminate & Low \\
\hline
\end{tabular}




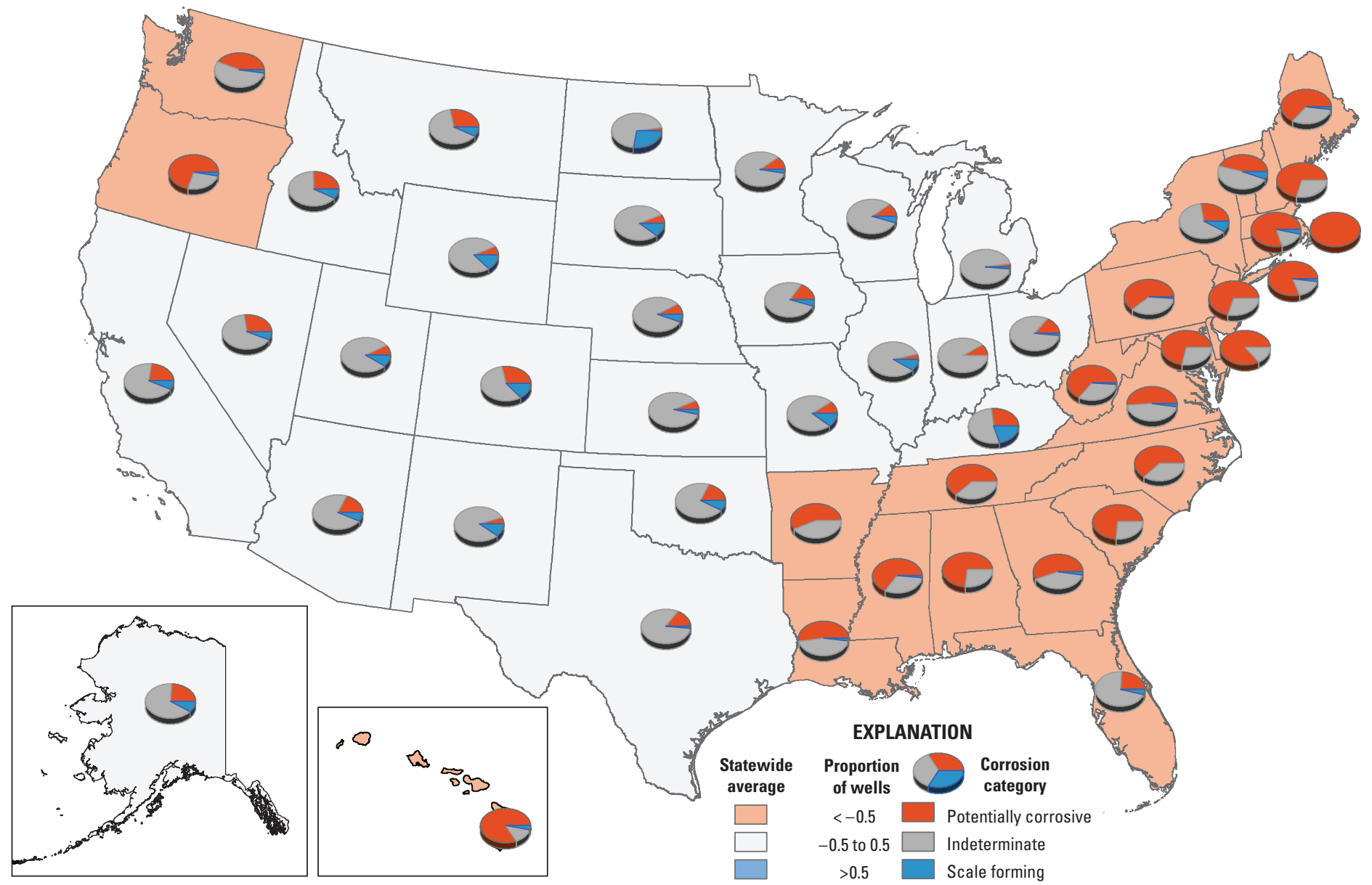

Figure 2. Pie charts and classifications based on Langelier Saturation Index for the 50 states and the District of Columbia. 
Table 3. Summary of the characteristic values, and the uncertainty in those values, of the Langelier Saturation Index (LSI) for the 50 states and the District of Columbia.

\begin{tabular}{|c|c|c|c|c|c|c|c|c|c|c|c|c|}
\hline \multirow[t]{2}{*}{ State } & \multicolumn{3}{|c|}{$\begin{array}{l}\text { Percentage of wells } \\
\text { classified as } \\
\text { potentially corrosive }\end{array}$} & \multicolumn{3}{|c|}{$\begin{array}{l}\text { Percentage of wells } \\
\text { classified as } \\
\text { indeterminate }\end{array}$} & \multicolumn{3}{|c|}{$\begin{array}{l}\text { Percentage of wells } \\
\text { classified as } \\
\text { scale forming }\end{array}$} & \multicolumn{3}{|c|}{ Average LSI } \\
\hline & $\begin{array}{l}\text { Lower } \\
\text { bound }\end{array}$ & Value & $\begin{array}{l}\text { Upper } \\
\text { bound }\end{array}$ & $\begin{array}{l}\text { Lower } \\
\text { bound }\end{array}$ & Value & $\begin{array}{l}\text { Upper } \\
\text { bound }\end{array}$ & $\begin{array}{l}\text { Lower } \\
\text { bound }\end{array}$ & Value & $\begin{array}{l}\text { Upper } \\
\text { bound }\end{array}$ & $\begin{array}{l}\text { Lower } \\
\text { bound }\end{array}$ & Value & $\begin{array}{l}\text { Upper } \\
\text { bound }\end{array}$ \\
\hline \multicolumn{13}{|c|}{ States classified as Potentially Corrosive based on average LSI $(<-0.5)$} \\
\hline Aabama & 67.3 & 72.9 & 77.7 & 21.7 & 26.6 & 32.1 & 0.0 & 0.5 & 2.2 & -3.22 & -2.95 & -2.68 \\
\hline Arkansas & 50.7 & 55.9 & 61.3 & 37.8 & 43.1 & 48.4 & 0.1 & 1.0 & 2.5 & -1.39 & -1.21 & -1.03 \\
\hline Connecticut & 75.3 & 80.4 & 84.9 & 13.1 & 17.5 & 22.5 & 0.7 & 2.1 & 4.6 & -2.17 & -2.00 & -1.84 \\
\hline District of Columbia & 70.2 & 86.7 & 94.0 & 5.0 & 13.3 & 29.3 & 0.0 & 0.0 & 7.8 & -2.96 & -2.48 & -2.01 \\
\hline Delaware & 82.4 & 86.2 & 89.1 & 10.7 & 13.8 & 17.6 & 0.0 & 0.0 & 0.8 & -3.62 & -3.44 & -3.25 \\
\hline Florida & 21.8 & 23.9 & 26.1 & 69.7 & 72.0 & 74.2 & 3.1 & 4.1 & 5.1 & -0.82 & -0.73 & -0.64 \\
\hline Georgia & 51.5 & 55.8 & 59.8 & 37.7 & 41.7 & 45.9 & 1.4 & 2.5 & 4.2 & -2.13 & -1.94 & -1.75 \\
\hline Hawaii & 75.3 & 83.8 & 90.4 & 6.9 & 13.2 & 21.2 & 0.5 & 2.9 & 8.7 & -1.51 & -1.35 & -1.19 \\
\hline Louisiana & 48.0 & 52.3 & 56.4 & 41.5 & 45.8 & 49.9 & 0.8 & 1.9 & 3.3 & -1.41 & -1.27 & -1.13 \\
\hline Massachusetts & 73.2 & 80.2 & 85.2 & 11.2 & 16.5 & 22.5 & 1.1 & 3.3 & 6.9 & -2.73 & -2.47 & -2.20 \\
\hline Maryland & 67.8 & 70.8 & 73.8 & 25.3 & 28.2 & 31.4 & 0.4 & 0.9 & 1.9 & -2.47 & -2.33 & -2.18 \\
\hline Maine & 54.6 & 64.0 & 72.2 & 25.3 & 33.7 & 42.8 & 0.4 & 2.3 & 7.1 & -1.78 & -1.51 & -1.24 \\
\hline Mississippi & 58.9 & 65.1 & 70.9 & 27.9 & 33.6 & 39.8 & 0.2 & 1.3 & 3.4 & -1.97 & -1.73 & -1.49 \\
\hline North Carolina & 58.2 & 61.7 & 64.9 & 34.0 & 37.4 & 40.7 & 0.3 & 0.9 & 1.8 & -1.92 & -1.80 & -1.67 \\
\hline New Hampshire & 62.6 & 70.7 & 78.3 & 21.4 & 29.3 & 37.2 & 0.0 & 0.0 & 2.3 & -2.09 & -1.82 & -1.54 \\
\hline New Jersey & 66.6 & 69.6 & 72.3 & 26.7 & 29.5 & 32.4 & 0.4 & 0.9 & 1.8 & -2.82 & -2.64 & -2.47 \\
\hline New York & 24.4 & 27.9 & 31.7 & 59.7 & 63.8 & 67.6 & 6.2 & 8.2 & 10.8 & -0.80 & -0.67 & -0.54 \\
\hline Oregon & 64.4 & 70.4 & 75.4 & 21.6 & 26.7 & 32.4 & 1.3 & 2.9 & 5.9 & -1.11 & -1.00 & -0.89 \\
\hline Pennsylvania & 58.1 & 61.4 & 64.5 & 34.5 & 37.6 & 40.8 & 0.5 & 1.0 & 2.0 & -1.26 & -1.16 & -1.06 \\
\hline Rhode Island & 68.1 & 100.0 & 100.0 & 0.0 & 0.0 & 29.8 & 0.0 & 0.0 & 29.8 & -3.87 & -3.29 & -2.70 \\
\hline South Carolina & 67.3 & 73.4 & 78.4 & 20.4 & 25.9 & 31.5 & 0.0 & 0.6 & 2.6 & -3.80 & -3.45 & -3.11 \\
\hline Tennessee & 57.9 & 61.9 & 65.8 & 33.9 & 37.8 & 41.8 & 0.1 & 0.3 & 1.5 & -1.80 & -1.63 & -1.46 \\
\hline Virginia & 47.8 & 51.2 & 54.5 & 43.5 & 46.7 & 50.1 & 1.2 & 2.1 & 3.2 & -1.25 & -1.15 & -1.05 \\
\hline Vermont & 31.2 & 45.7 & 60.1 & 33.8 & 48.6 & 62.8 & 1.0 & 5.7 & 16.7 & -1.01 & -0.74 & -0.47 \\
\hline Washington & 39.6 & 43.5 & 47.7 & 50.1 & 54.3 & 58.2 & 1.1 & 2.2 & 3.7 & -0.80 & -0.71 & -0.63 \\
\hline West Virginia & 61.3 & 64.7 & 68.0 & 30.9 & 34.2 & 37.6 & 0.5 & 1.0 & 2.1 & -1.40 & -1.27 & -1.14 \\
\hline \multicolumn{13}{|c|}{ States classified as Indeterminate based on average LSI $(>=-0.5$ and $<=0.5$ ) } \\
\hline Alaska & 15.5 & 24.1 & 36.5 & 55.1 & 67.2 & 77.4 & 2.7 & 8.6 & 16.6 & -0.34 & -0.19 & -0.04 \\
\hline Arizona & 16.0 & 18.0 & 20.1 & 72.8 & 75.1 & 77.4 & 5.5 & 6.8 & 8.3 & -0.22 & -0.18 & -0.14 \\
\hline California & 21.9 & 23.0 & 24.0 & 69.1 & 70.2 & 71.3 & 6.2 & 6.8 & 7.5 & -0.23 & -0.21 & -0.20 \\
\hline Colorado & 26.5 & 28.6 & 30.9 & 56.1 & 58.5 & 60.8 & 11.3 & 12.9 & 14.5 & -0.35 & -0.29 & -0.23 \\
\hline Iowa & 13.1 & 15.6 & 18.2 & 76.6 & 79.5 & 82.3 & 3.5 & 4.9 & 6.6 & -0.22 & -0.17 & -0.12 \\
\hline Idaho & 23.5 & 25.3 & 27.1 & 65.5 & 67.4 & 69.3 & 6.3 & 7.3 & 8.5 & -0.35 & -0.24 & -0.13 \\
\hline Illinois & 2.2 & 4.1 & 6.6 & 83.0 & 86.9 & 90.2 & 6.3 & 9.0 & 12.6 & -0.00 & 0.05 & 0.10 \\
\hline Indiana & 6.1 & 9.0 & 13.1 & 85.7 & 90.1 & 92.9 & 0.2 & 0.9 & 3.0 & -0.23 & -0.13 & -0.02 \\
\hline Kansas & 4.8 & 6.8 & 9.7 & 86.5 & 89.8 & 92.2 & 1.9 & 3.4 & 5.4 & -0.07 & -0.02 & 0.02 \\
\hline Kentucky & 15.5 & 26.7 & 43.3 & 37.3 & 53.3 & 67.6 & 8.5 & 20.0 & 33.2 & -0.77 & -0.24 & 0.29 \\
\hline Michigan & 1.0 & 2.4 & 5.4 & 92.6 & 95.7 & 97.7 & 0.7 & 1.8 & 4.7 & -0.06 & -0.02 & 0.02 \\
\hline Minnesota & 7.9 & 10.3 & 13.1 & 83.6 & 86.8 & 89.3 & 1.7 & 2.9 & 4.8 & -0.07 & -0.03 & 0.01 \\
\hline Missouri & 7.1 & 9.6 & 12.5 & 76.0 & 79.7 & 83.1 & 8.1 & 10.7 & 13.7 & -0.04 & 0.02 & 0.08 \\
\hline Montana & 24.9 & 28.3 & 32.2 & 60.1 & 64.2 & 67.9 & 5.5 & 7.5 & 9.9 & -0.55 & -0.45 & -0.35 \\
\hline North Dakota & 1.1 & 2.3 & 3.9 & 66.2 & 70.3 & 74.2 & 23.6 & 27.4 & 31.5 & 0.25 & 0.30 & 0.35 \\
\hline Nebraska & 6.8 & 8.5 & 10.3 & 83.4 & 85.6 & 87.8 & 4.5 & 5.9 & 7.5 & -0.02 & 0.02 & 0.07 \\
\hline New Mexico & 3.6 & 5.2 & 7.0 & 81.8 & 84.8 & 87.3 & 8.0 & 10.1 & 12.7 & 0.04 & 0.09 & 0.15 \\
\hline Nevada & 25.2 & 27.6 & 30.1 & 63.4 & 66.1 & 68.6 & 5.1 & 6.4 & 7.9 & -0.28 & -0.25 & -0.21 \\
\hline Ohio & 11.9 & 14.6 & 17.7 & 80.6 & 83.8 & 86.5 & 0.7 & 1.5 & 2.9 & -0.27 & -0.21 & -0.15 \\
\hline Oklahoma & 15.1 & 18.1 & 21.6 & 70.6 & 74.4 & 78.0 & 5.3 & 7.4 & 9.8 & -0.33 & -0.25 & -0.16 \\
\hline South Dakota & 4.5 & 6.5 & 9.3 & 78.6 & 82.5 & 85.7 & 8.2 & 11.0 & 14.3 & -0.06 & -0.01 & 0.03 \\
\hline Texas & 13.7 & 15.5 & 17.3 & 81.3 & 83.2 & 85.0 & 0.8 & 1.3 & 2.0 & -0.38 & -0.34 & -0.30 \\
\hline Utah & 6.4 & 7.9 & 9.6 & 80.3 & 82.6 & 84.7 & 8.0 & 9.5 & 11.4 & 0.01 & 0.04 & 0.07 \\
\hline Wisconsin & 7.3 & 10.3 & 13.8 & 80.8 & 84.9 & 88.3 & 2.9 & 4.7 & 7.7 & -0.22 & -0.14 & -0.07 \\
\hline Wyoming & 5.5 & 7.1 & 8.9 & 77.2 & 80.0 & 82.4 & 10.7 & 12.9 & 15.1 & 0.04 & 0.08 & 0.12 \\
\hline
\end{tabular}




\section{Potential to Promote Galvanic Corrosion}

The PPGC was mapped at a national scale by using data from 26,631 groundwater sites (fig. 3; table 2). Nationally, 8 percent of the groundwater sites were classified as having a high PPGC, 67 percent as moderate, and 26 percent as low (Belitz and others, 2016b). Potentially corrosive groundwater occurs broadly across the United States (table 4; fig. 4).

Thirty-three states are classified as moderate with respect to
PPGC. The population dependent on self-supplied groundwater in those 33 states is 34 million people (table 2). Eleven states and the District of Columbia are classified as high with respect to PPGC. These states are located in the Northeast, mid-Atlantic, and Southeast. The population dependent on self-supplied groundwater in the 11 states (excluding the District of Columbia) classified as high PPGC is 8 million people (table 3).

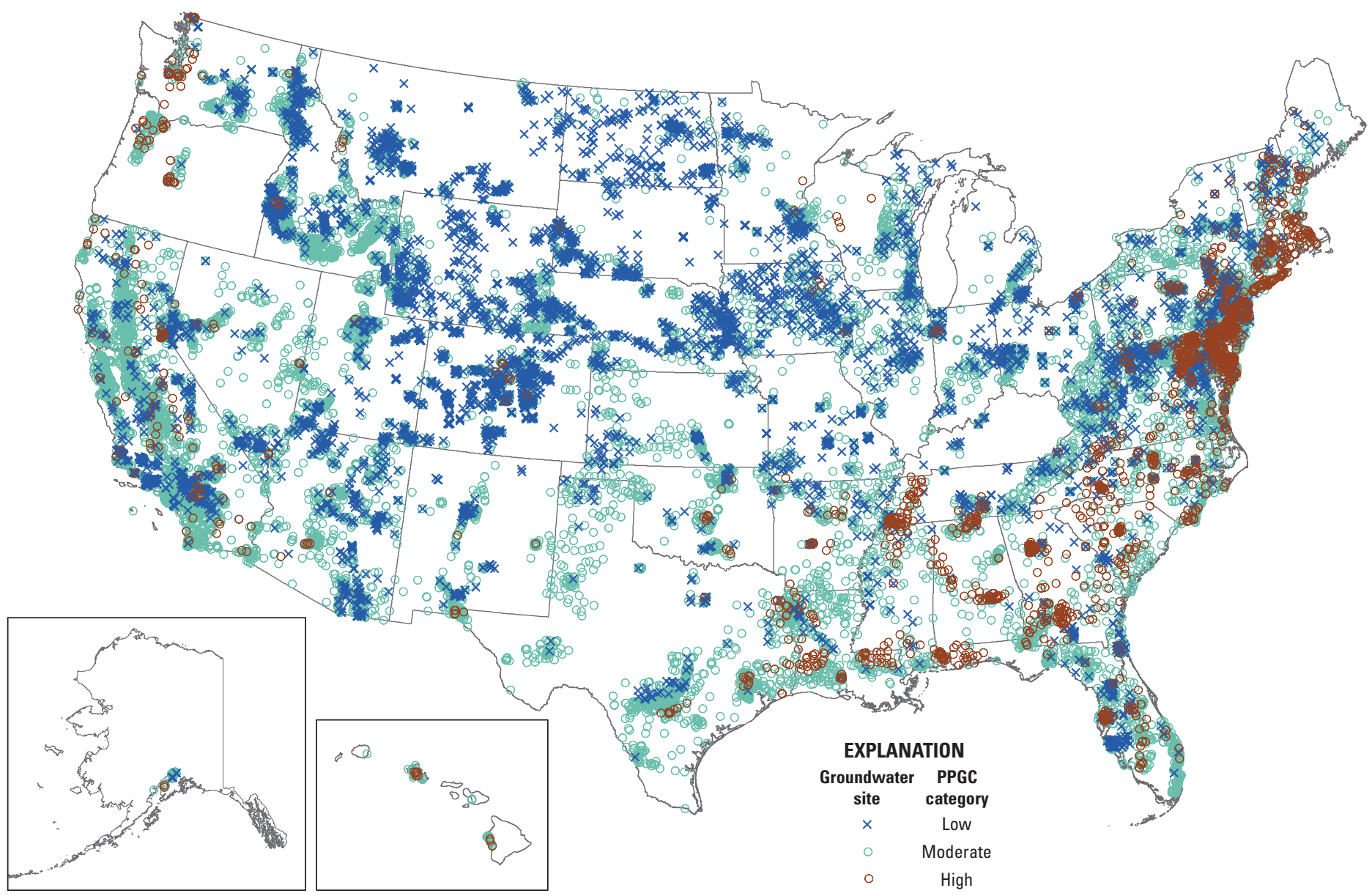

Figure 3. Potential to Promote Galvanic Corrosion for 26,631 groundwater sites in the United States. PPGC, Potential to Promote Galvanic Corrosion. 
Table 4. Summary of the characteristic values, and the uncertainty in those values, of the Potential to Promote Galvanic Corrosion (PPGC) for the 50 states and the District of Columbia.

\begin{tabular}{|c|c|c|c|c|c|c|c|c|c|}
\hline \multirow{2}{*}{ State } & \multicolumn{3}{|c|}{$\begin{array}{l}\text { Percentage of wells classified as } \\
\text { low PPGC }\end{array}$} & \multicolumn{3}{|c|}{$\begin{array}{l}\text { Percentage of wells classified as } \\
\text { moderate PPGC }\end{array}$} & \multicolumn{3}{|c|}{$\begin{array}{c}\text { Percentage of wells classified as } \\
\text { high PPGC }\end{array}$} \\
\hline & $\begin{array}{l}\text { Lower } \\
\text { bound }\end{array}$ & Value & $\begin{array}{l}\text { Upper } \\
\text { bound }\end{array}$ & $\begin{array}{l}\text { Lower } \\
\text { bound }\end{array}$ & Value & $\begin{array}{l}\text { Upper } \\
\text { bound }\end{array}$ & $\begin{array}{l}\text { Lower } \\
\text { bound }\end{array}$ & Value & $\begin{array}{l}\text { Upper } \\
\text { bound }\end{array}$ \\
\hline \multicolumn{10}{|c|}{ States classified as High PPGC, Less than 50 percent of wells are low and more than 25 percent of wells are high } \\
\hline Alabama & 1.9 & 3.8 & 6.8 & 39.9 & 45.7 & 51.5 & 44.6 & 50.5 & 56.2 \\
\hline Connecticut & 4.0 & 6.7 & 10.4 & 48.7 & 54.9 & 60.8 & 32.6 & 38.5 & 44.4 \\
\hline District of Columbia & 3.0 & 10.7 & 25.0 & 36.6 & 53.6 & 68.9 & 20.8 & 35.7 & 52.2 \\
\hline Delaware & 5.0 & 7.3 & 10.2 & 34.4 & 39.1 & 43.9 & 48.7 & 53.6 & 58.4 \\
\hline Georgia & 9.8 & 12.4 & 15.5 & 51.5 & 55.7 & 59.8 & 28.0 & 31.8 & 35.8 \\
\hline Massachusetts & 6.1 & 10.1 & 15.5 & 33.0 & 40.3 & 47.7 & 42.0 & 49.6 & 57.0 \\
\hline Maryland & 19.7 & 22.4 & 25.3 & 41.8 & 45.2 & 48.5 & 29.3 & 32.4 & 35.6 \\
\hline Maine & 11.1 & 17.4 & 25.4 & 37.3 & 46.5 & 55.6 & 27.4 & 36.0 & 45.2 \\
\hline New Hampshire & 24.2 & 32.0 & 40.4 & 33.8 & 42.3 & 50.9 & 18.6 & 25.8 & 33.9 \\
\hline New Jersey & 14.7 & 16.9 & 19.3 & 52.1 & 55.2 & 58.2 & 25.2 & 27.9 & 30.7 \\
\hline Rhode Island & 0.0 & 0.0 & 29.8 & 0.0 & 0.0 & 29.8 & 68.1 & 100.0 & 100.0 \\
\hline South Carolina & 6.0 & 9.3 & 13.6 & 38.1 & 44.3 & 50.5 & 40.2 & 46.4 & 52.7 \\
\hline \multicolumn{10}{|c|}{ States classified as Moderate PPGC, Less than 50 percent of wells are low and 25 percent or less of wells are high } \\
\hline Alaska & 3.9 & 9.6 & 19.0 & 76.2 & 86.5 & 92.9 & 0.7 & 3.8 & 11.5 \\
\hline Arkansas & 12.5 & 16.3 & 20.6 & 71.5 & 76.4 & 80.7 & 4.8 & 7.3 & 10.6 \\
\hline Arizona & 27.4 & 29.8 & 32.3 & 66.8 & 69.3 & 71.7 & 0.5 & 0.9 & 1.6 \\
\hline California & 12.0 & 12.8 & 13.7 & 84.2 & 85.1 & 86.0 & 1.7 & 2.0 & 2.4 \\
\hline Florida & 12.4 & 14.1 & 15.9 & 75.5 & 77.7 & 79.7 & 6.9 & 8.2 & 9.7 \\
\hline Hawaii & 0.0 & 0.0 & 3.2 & 75.3 & 84.3 & 90.4 & 9.1 & 15.7 & 24.5 \\
\hline Iowa & 35.9 & 39.3 & 42.7 & 56.5 & 60.0 & 63.4 & 0.2 & 0.7 & 1.6 \\
\hline Idaho & 21.8 & 23.5 & 25.3 & 74.5 & 76.3 & 78.0 & 0.1 & 0.2 & 0.5 \\
\hline Illinois & 26.7 & 31.5 & 36.6 & 63.4 & 68.5 & 73.2 & 0.0 & 0.0 & 0.9 \\
\hline Indiana & 29.7 & 35.3 & 41.0 & 57.4 & 63.3 & 68.7 & 0.4 & 1.4 & 3.7 \\
\hline Kansas & 26.1 & 30.3 & 34.7 & 65.3 & 69.7 & 73.8 & 0.0 & 0.0 & 0.7 \\
\hline Kentucky & 31.5 & 46.9 & 61.9 & 37.3 & 53.1 & 67.6 & 0.0 & 0.0 & 6.8 \\
\hline Louisiana & 4.4 & 6.3 & 8.7 & 75.2 & 78.9 & 82.1 & 12.0 & 14.8 & 18.1 \\
\hline Michigan & 23.8 & 29.2 & 35.0 & 65.0 & 70.8 & 76.0 & 0.0 & 0.0 & 1.2 \\
\hline Minnesota & 24.4 & 28.1 & 32.0 & 67.5 & 71.4 & 75.1 & 0.1 & 0.5 & 1.6 \\
\hline Missouri & 42.7 & 47.2 & 51.6 & 48.0 & 52.5 & 56.9 & 0.0 & 0.3 & 1.3 \\
\hline Mississippi & 12.2 & 16.6 & 21.7 & 61.2 & 67.4 & 73.0 & 11.7 & 16.0 & 21.1 \\
\hline North Carolina & 8.3 & 10.3 & 12.6 & 63.1 & 66.4 & 69.6 & 20.4 & 23.2 & 26.3 \\
\hline New Mexico & 22.8 & 26.0 & 29.4 & 69.3 & 72.8 & 76.0 & 0.5 & 1.2 & 2.4 \\
\hline Nevada & 20.1 & 22.3 & 24.7 & 74.2 & 76.6 & 78.8 & 0.6 & 1.1 & 1.8 \\
\hline New York & 13.7 & 16.6 & 19.8 & 64.8 & 68.7 & 72.4 & 11.9 & 14.7 & 17.8 \\
\hline Ohio & 36.0 & 39.9 & 43.8 & 55.5 & 59.5 & 63.3 & 0.2 & 0.7 & 1.7 \\
\hline Oklahoma & 7.3 & 9.6 & 12.4 & 84.3 & 87.4 & 89.9 & 1.8 & 3.0 & 4.9 \\
\hline Oregon & 0.4 & 1.5 & 3.9 & 75.6 & 80.8 & 85.1 & 13.4 & 17.7 & 22.7 \\
\hline Pennsylvania & 23.7 & 26.5 & 29.4 & 62.9 & 66.1 & 69.1 & 5.8 & 7.5 & 9.4 \\
\hline Tennessee & 21.2 & 24.6 & 28.2 & 55.1 & 59.2 & 63.0 & 13.4 & 16.2 & 19.4 \\
\hline Texas & 4.4 & 5.5 & 6.8 & 90.0 & 91.5 & 92.8 & 2.2 & 3.0 & 4.0 \\
\hline Utah & 27.1 & 29.7 & 32.3 & 67.5 & 70.2 & 72.8 & 0.0 & 0.1 & 0.6 \\
\hline Virginia & 10.3 & 12.4 & 14.7 & 69.2 & 72.3 & 75.2 & 13.0 & 15.3 & 17.9 \\
\hline Vermont & 16.4 & 28.6 & 43.1 & 47.6 & 62.9 & 75.6 & 2.4 & 8.6 & 20.4 \\
\hline Washington & 15.4 & 18.4 & 21.7 & 70.6 & 74.3 & 77.7 & 5.3 & 7.3 & 9.7 \\
\hline Wisconsin & 16.7 & 20.8 & 25.2 & 73.1 & 77.7 & 81.7 & 0.5 & 1.5 & 3.4 \\
\hline West Virginia & 27.4 & 30.5 & 33.8 & 63.3 & 66.7 & 69.9 & 1.8 & 2.8 & 4.2 \\
\hline \multicolumn{10}{|c|}{ States classified as Low PPGC, More than $\mathbf{5 0}$ percent of wells are low } \\
\hline Colorado & 59.3 & 61.7 & 64.0 & 35.4 & 37.7 & 40.0 & 0.3 & 0.7 & 1.2 \\
\hline Montana & 61.5 & 65.5 & 69.2 & 30.0 & 33.8 & 37.7 & 0.2 & 0.7 & 1.8 \\
\hline North Dakota & 77.6 & 81.3 & 84.4 & 15.5 & 18.8 & 22.4 & 0.0 & 0.0 & 0.6 \\
\hline Nebraska & 58.3 & 61.4 & 64.4 & 35.5 & 38.6 & 41.6 & 0.0 & 0.0 & 0.3 \\
\hline South Dakota & 55.8 & 60.5 & 65.0 & 34.6 & 39.2 & 43.8 & 0.0 & 0.3 & 1.5 \\
\hline Wyoming & 57.5 & 60.7 & 63.8 & 36.2 & 39.3 & 42.5 & 0.0 & 0.0 & 0.3 \\
\hline
\end{tabular}




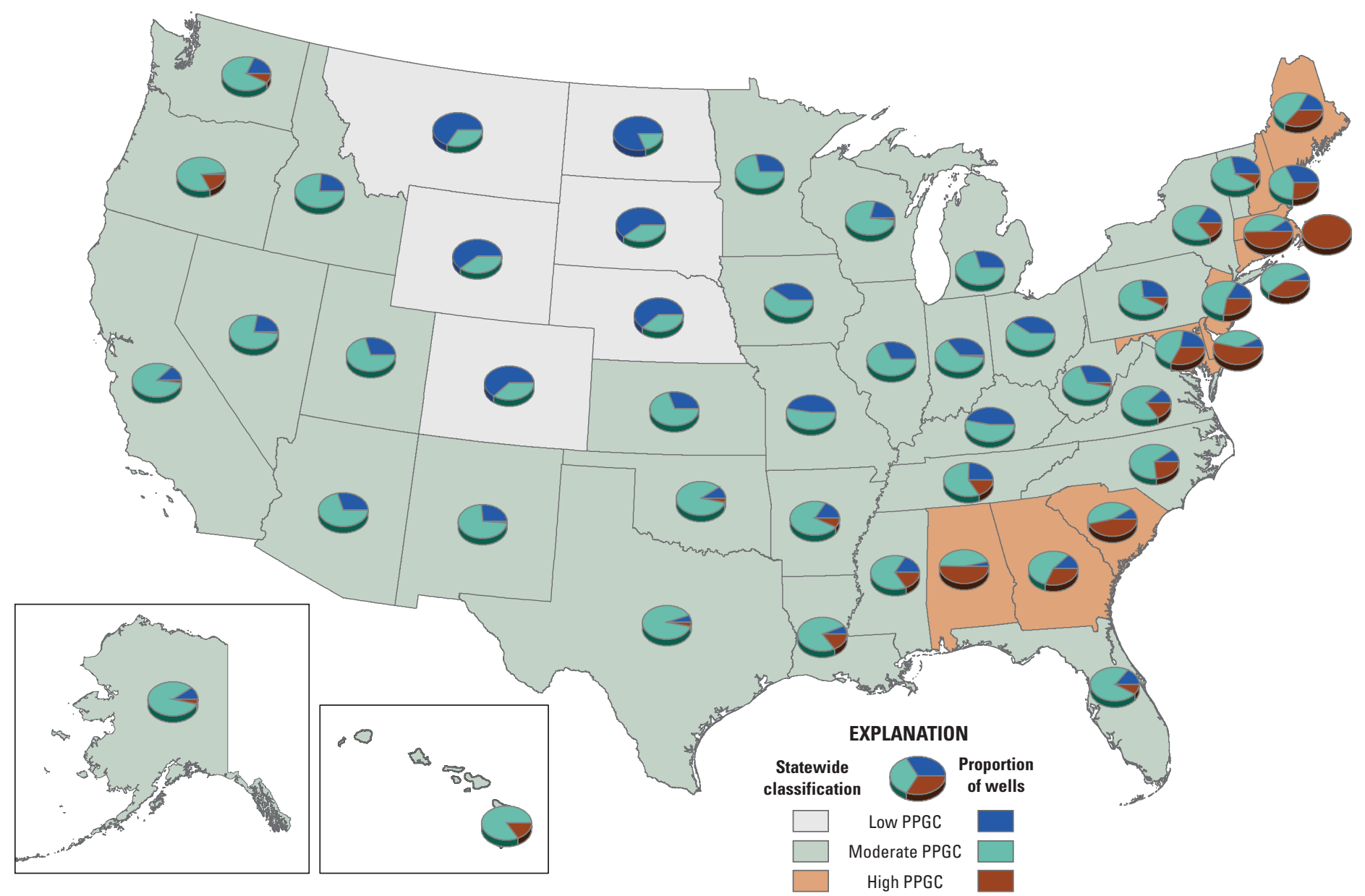

Figure 4. Pie charts and classifications based on Potential to Promote Galvanic Corrosion for the 50 states and the District of Columbia. 


\section{Combined Index: State-Scale Prevalence of Potentially Corrosive Groundwater}

The state-scale prevalence of potentially corrosive groundwater was evaluated by combining the classifications of the states that were based on LSI and PPGC. Given that there are three state-scale classifications for LSI and three state-scale classifications for PPGC, there are nine possible combinations for the combined index (CI). However, only four of the nine possibilities occur given the data presented in this report (fig. 5). Consequently, four classes of prevalence are identified: very high, high, moderate, and low (fig. 5). Eleven states and the District of Columbia are classified as having a very high prevalence based on the CI; 8 million people are dependent on self-supplied groundwater in those states. Fourteen states are classified as having a high prevalence based on the CI; 16 million people are dependent on self-supplied groundwater in those states. Nineteen states are classified as having a moderate prevalence based on the CI; 18 million people are dependent on self-supplied water in those states. Six states are classified as having a low prevalence based on the CI, with 1 million people dependent on self-supplied groundwater (fig. 6; table 2).

\begin{tabular}{|c|c|c|c|c|}
\hline & \multicolumn{3}{|c|}{ PPGC Class } \\
\hline & & High & Moderate & Low \\
\hline \multirow{3}{*}{$\begin{array}{l}\frac{\mathscr{0}}{0} \\
\frac{\pi}{\omega} \\
\frac{5}{\omega}\end{array}$} & Potentially corrosive & Very high & High & NA \\
\hline & Indeterminate & NA & Moderate & Low \\
\hline & Scale forming & NA & NA & NA \\
\hline
\end{tabular}

Figure 5. Classification system for identifying the statescale prevalence of potentially corrosive groundwater. LSI, Langelier Saturation Index; PPGC, Potential to Promote Galvanic Corrosion.

The states that were classified as very high prevalence and high prevalence based on the CI are generally located in the Northeast, mid-Atlantic, Southeast, and Northwest. Hawaii was also classified as high prevalence based on the CI. The states that were classified as moderate prevalence based on the $\mathrm{CI}$ are broadly distributed. The six states classified as low prevalence based on the CI are Colorado, Montana, Nebraska, North Dakota, South Dakota, and Wyoming.

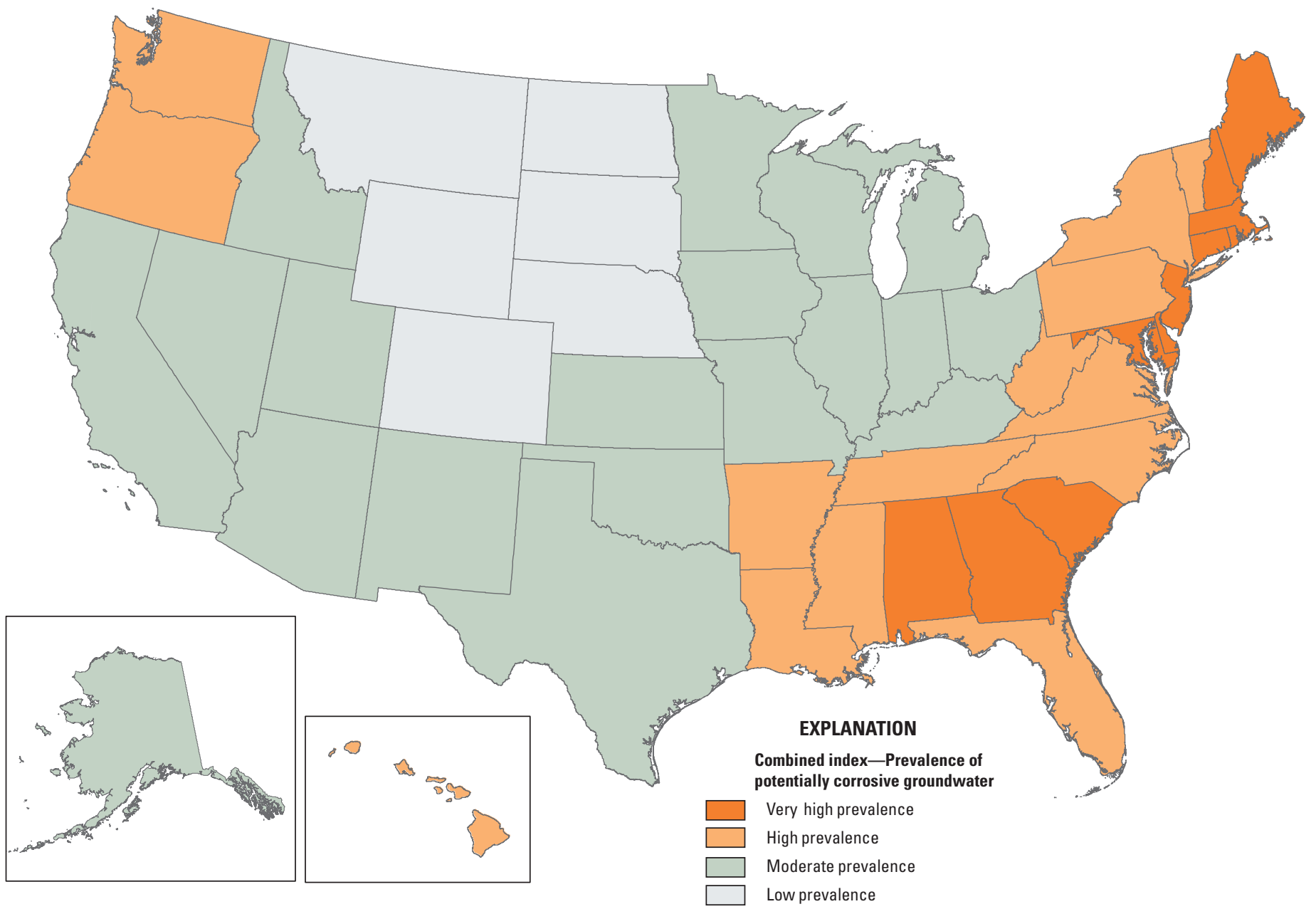

Figure 6. The prevalence of potentially corrosive groundwater for the 50 states and the District of Columbia. 


\section{Uncertainty in Estimates of Characteristic Values and Classification of States}

Classification of the states with respect to LSI, PPGC, and CI was based on estimates of characteristic values for each state, and those estimates are subject to uncertainty. Confidence intervals for the average LSI for each state were computed (appendix 1) and compiled (table 3). Confidence intervals for the proportions of wells in states classified as low PPGC, moderate PPGC, and high PPGC were also computed (appendix 1) and compiled (table 4). Given a 90-percent confidence interval, six states could be assigned a classification that is different from the classification based on the characteristic value for that state: Kentucky, Missouri, Montana, New Hampshire, North Carolina, and Vermont. The classification of the remaining 44 states and the District of Columbia are not sensitive to uncertainty given the 90-percent confidence interval associated with the estimates of the characteristic values. If, however, the groundwater sites used to characterize a state are not broadly distributed across the various aquifers of a state, then the characteristic value derived from the data might not be an accurate representation of that state. Examples include, but are not limited to, Alaska, Kentucky, and Oregon. Quantitative assessment of uncertainty associated with the spatial distribution of the data within a state is beyond the scope of this report.

\section{State-Scale Potential Corrosivity and Occurrence of Lead in Water from Households Dependent on Self-Supplied Groundwater}

It is important to understand the relation between the potential corrosivity of groundwater and the occurrence of lead in water in households dependent on self-supplied groundwater because the U.S. Environmental Protection Agency (EPA) reports that there is no known safe level of lead in a child's blood (U.S. Environmental Protection Agency, 2016). A qualitative understanding of the relation can be obtained by comparing data obtained from state-scale surveys of lead in water from households dependent on self-supplied groundwater (Pieper and others, 2015) to the results presented in this report. A summary of published data for three states - North Carolina, Pennsylvania (two surveys), and Virginia - is presented in table 5. The reporting levels in the Pennsylvania and Virginia surveys are equal to the EPA action level for lead (15 micrograms per liter). The reporting level in the North Carolina survey is less than the EPA action level; consequently, the detection frequency reported in table 5 is likely higher than it would have been if the reporting level were at the action level. All three states, based on the CI, were classified as high prevalence, but North Carolina could be classified as very high prevalence given the uncertainty in estimating the characteristic values (appendix 1). The detection frequency of lead in the three states ranged from 12 to 34 percent (table 5).

Of the three states, North Carolina had the largest lead detection frequency (albeit at a lower reporting level) and Pennsylvania had the smallest (table 5). The characteristic values for LSI and PPGC suggest that groundwater in North Carolina is the most potentially corrosive of the three states: the smallest average LSI, the smallest percentage of wells classified as low PPGC, and the largest percentage of wells classified as high PPGC (table 5). The characteristic values suggest that groundwater in Pennsylvania is the least potentially corrosive of the three states: the largest percentage of wells classified as low PPGC and the smallest percentage of wells classified as high PPGC; the average LSI is the same as Virginia (table 5). Qualitatively, there is agreement between the potential corrosivity of groundwater as indicated by the LSI and PPGC indices and the detection frequencies for lead (table 5). Given that these data are summaries for only three states, that the three states have the same classification based on the CI, and that the reporting level for North Carolina was less than the other two states, additional work would be needed to better understand the relations between the potential corrosivity of groundwater and the occurrence of lead in water from households dependent on self-supplied groundwater.

Table 5. Summary of the surveys of lead detection frequency in samples from households dependent on self-supplied groundwater.

[ $\mu \mathrm{g} / \mathrm{L}$, microgram per liter; LSI, Langelier Saturation index; PPGC, Potential to Promote Galvanic Corrosion]

\begin{tabular}{|c|c|c|c|c|c|c|c|c|}
\hline State & $\begin{array}{l}\text { Number of } \\
\text { samples }\end{array}$ & $\begin{array}{c}\text { Reporting } \\
\text { level } \\
\text { ( } \mu \mathrm{g} / \mathrm{L})\end{array}$ & $\begin{array}{l}\text { Lead detection } \\
\text { frequency above } \\
\text { reporting level } \\
\text { (percent) }\end{array}$ & $\begin{array}{c}\text { Average } \\
\text { LSI }\end{array}$ & $\begin{array}{l}\text { PPGC, } \\
\text { percent } \\
\text { low }\end{array}$ & $\begin{array}{c}\text { PPGC, } \\
\text { percent } \\
\text { moderate }\end{array}$ & $\begin{array}{l}\text { PPGC, } \\
\text { percent } \\
\text { high }\end{array}$ & Reference \\
\hline North Carolina & 605 & 10 & 34 & -1.8 & 10 & 66 & 23 & Maas and Patch (1990) \\
\hline Pennsylvania & 1,595 & 15 & 19 & -1.2 & 26 & 66 & 7 & Swistock and others (1993) \\
\hline Pennsylvania & 251 & 15 & 12 & -1.2 & 26 & 66 & 7 & $\begin{array}{l}\text { Swistock and Clemens } \\
\text { (2013) }\end{array}$ \\
\hline United States & 2,564 & 50 & 9 & -0.67 & 26 & 67 & 8 & Francis and others (1982) \\
\hline
\end{tabular}


Table 5 also presents results from a national survey of rural water in the United States (Francis and others, 1982, as cited by Pieper and others, 2015). The reporting level in the national survey was greater than the EPA action level for lead. The national results are indicative of the extent to which lead might be present in the water from households dependent on self-supplied groundwater.

The potential corrosivity of groundwater is one of many factors that can affect the occurrence of lead in drinking water (U.S. Environmental Protection Agency, 2016). These factors include, but are not limited to the following: the composition of the pipes and other components in a distribution system, both prior to and within the household; the amount of time that water is in contact with pipes and other components; the presence or absence of particulates; and additional reactions, particularly those involving constituents not included in the LSI and PPGC indices. Also, treatment and changes in treatment can increase or decrease the concentration of lead in household water supply (Edwards and Triantafyllidou, 2007). The indices and maps presented in this report do not address these additional factors.

\section{Summary and Conclusions}

The potential corrosivity of groundwater in the United States was mapped at a national scale using data from about 27,000 groundwater sites. Two indicators were used to characterize potential corrosivity: the Langelier Saturation Index (LSI) and the Potential to Promote Galvanic Corrosion (PPGC). The LSI is an indicator of whether a calcium carbonate scale might form on the inside of pipes and other components in a distribution system. In the absence of a protective scale, lead, if present, may dissolve into the water. Galvanic corrosion of lead is an electrochemical process that can occur when lead pipe or lead solder is in contact with dissimilar metals such as copper.

For each indicator, two national maps were developed. The first map shows the values of the indicator at individual groundwater sites. The second map shows, for each state, a pie chart illustrating the distribution of the values of the indicator within that state and a classification of the potential corrosivity of groundwater for that state. On the basis of LSI, about one-third of the 20,962 sampled groundwater sites and 25 states and the District of Columbia were classified as potentially corrosive. On the basis of PPGC, about two-thirds of the 26,631 sampled groundwater sites and 14 states were classified as having a moderate PPGC. On the basis of PPGC, 8 percent of the groundwater sites and 11 states and the District of Columbia were classified as having a high PPGC. Potentially corrosive groundwater occurs in all 50 states and the District of Columbia.

A map of state-scale prevalence of potentially corrosive groundwater, obtained by combining the state-scale classifications of LSI and PPGC, was also developed. Eleven states and the District of Columbia were classified as having a very high prevalence based on the combined index (CI); 8 million people dependent on self-supplied groundwater reside in those states. Fourteen states, with 16 million people dependent on self-supplied groundwater, were classified as having a high prevalence based on the CI. Nineteen states, with 18 million people dependent on self-supplied groundwater, were classified as having a moderate prevalence based on the CI. Six states, with 1 million people dependent on self-supplied groundwater, were classified has having a low prevalence based on the CI. Self-supplied groundwater typically is obtained from domestic wells, but sometimes is obtained from springs.

The states that were classified as very high prevalence and high prevalence based on the CI are generally located in the Northeast, mid-Atlantic, Southeast, and Northwest. Hawaii was also classified as high prevalence based on the CI. The states that were classified as moderate prevalence based on the CI are broadly distributed. The six states classified as low prevalence based on the CI are Colorado, Montana, Nebraska, North Dakota, South Dakota, and Wyoming.

The indices and maps presented in this report are a first step in making an assessment of groundwater corrosivity. Additional steps could include identification and evaluation of additional indices of corrosivity, and evaluation of the relation between the indices and the factors that may affect groundwater corrosivity. These factors include, but are not limited to, aquifer type, mineralogy of the aquifer materials, distance of the well from recharge areas, depth of the well, groundwater age, climate, and proximity to sources of salinity.

\section{References Cited}

Belitz, Kenneth, Jurgens, B.C., Johnson, T.D., 2016a, Langelier Saturation Indices computed for U.S. groundwater, 1991-2015; Water well data and characteristic values for states: U.S. Geological Survey data release, accessed July 12, 2016, at http://dx.doi.org/10.5066/F7XW4GWX.

Belitz, Kenneth, Jurgens, B.C., Johnson, T.D., 2016b, Classification of chloride-to-sulfate mass ratio for U.S. groundwater with respect to the Potential to Promote Galvanic Corrosion of lead, 1991-2015; Water well data and characteristic values for states: U.S. Geological Survey data release, accessed July 12, 2016, at http://dx.doi.org/10.5066/ F7MC8X40.

Brown, L.D., Cai, T.T., and DasGupta, A., 2001, Interval estimation for a binomial proportion, Statistical Science, v. 16, no. 2, p. 101-133.

Clopper, C.J., and Pearson, E.S., 1934, The use of confidence intervals or fiducial limits illustrated in the case of the binomial: Biometrika, v. 26, no. 4, p. 404-413. 
Edwards, M., and Triantafyllidou, S., 2007, Chloride-tosulfate mass ratio and lead leaching to water: Journal of American Water Works Association, v. 99, no. 7, p. 96-109.

Francis, J.D., Brewer, B.L., Graham, W.F., Larson, O.W., McCaull, J.L., and Vigorita, H.M., 1982, National statistical assessment of rural water conditions: U.S. Environmental Protection Agency, Office of Drinking Water.

Garrels, R.M., and Christ, C.L., 1965, Solutions, minerals, and equilibria: San Francisco, Freemans, Cooper \& Company, $450 \mathrm{p}$.

Gregory, R., 1985, Galvanic corrosion of lead in copper pipework-Phase I, measurement of galvanic corrosion potential in selected waters: Swindon, England, Water Research Centre Engineering, 74 p.

Hem, J.D., 1985, Study and interpretation of the chemical characteristics of natural water, U.S. Geological Survey Water Supply Paper 2254, 264 p.

Hu, J., Gan, F., Triantafyllidou, S., Nguyen, C.K., and Edwards, M.A., 2012, Copper-induced metal release from lead pipe into drinking water: Corrosion, v. 68 , no. 11 , p. 1037-1048, accessed March 10, 2016, at http://dx.doi. org/10.5006/0616.

Langelier, W.F., 1936, The analytical control of anti-corrosion water treatment: Journal of the American Water Works Association, v. 28, no. 10, p. 1500-1521.

Langland, M.J., and Dugas, D.L., 1996, Assessment of severity and distribution of corrosive ground water in Pennsylvania: U.S. Geological Survey Open-File Report 95-377, 2 pls.

Larson, T.E., Buswell, A.M., Ludwig, H.F., and Langelier, W.F., 1942, Calcium carbonate saturation index and alkalinity interpretations [with discussion]: Journal of the American Water Works Association, v. 34, no. 11, p. 1667-1684.

Maas, R.P., and Patch, S.C., 1990, Lead contamination of North Carolina domestic tapwater-Prevalence, risk factors, and control measures: Asheville, N.C., UNCAsheville Environmental Quality Institute Technical Report No. 90-003.

Maupin, M.A., Kenny, J.F., Hutson, S.S., Lovelace, J.K., Barber, N.L., and Linsey, K.S., 2014, Estimated use of water in the United States in 2010: U.S. Geological Survey Circular 1405, 56 p., accessed April 12, 2016, at http://dx.doi.org/10.3133/cir1405.
Nguyen, C., Stone, K., Clark, B., Edwards, M., Gagnon, G., and Knowles, A., 2010, Impact of chloride-Sulfate mass ratio (CSMR) changes on lead leaching in potable water: Denver, Water Research Foundation, 198 p.

Nguyen, C.K., Stone, K.R., and Edwards, M.A., 2011, Chloride-to-sulfate mass ratio-Practical studies in galvanic corrosion of lead solder: Journal of the American Water Works Association, v. 103, no. 1, p. 81-92.

Ott, R.L., and Longnecker, M., 2001, An introduction to statistical methods and data analysis (5th ed.): Pacific Grove, Calif., Duxbury Press, 1,152 p.

Pieper, K.J., Krometis, L.A.H., Gallagher, D.L., Benham, B.L., and Edwards, M., 2015, Incidence of waterborne lead in private drinking water systems in Virginia: Journal of Water and Health, v. 13, no. 3, p. 897-908, accessed April 6, 2016, at http://dx.doi.org/10.2166/wh.2015.275.

Roberge, P.R., 2007, Corrosion inspection and monitoring: New York, John Wiley \& Sons, appendix B, 4 p., accessed April 18, 2016, at http://dx.doi.org/10.1002/ 9780470099766.app2.

Singley, J.E., Beaudet, B.A., and Markey, P.H., 1984, Corrosion manual for internal corrosion of water distribution systems: Gainesville, Fla., Environmental Science and Engineering, Inc., No. ORNL/TM-8919; EPA-570/9-84-001.

Stumm, W., and Morgan, J.J., 1981, Aquatic chemistry-An introduction emphasizing chemical equilibria in natural waters: New York, John Wiley, 780 p.

Swistock, B.R., and Clemens, S., 2013, Water quality and management of private drinking water wells in Pennsylvania: Journal of Environmental Health, v. 75, no. 6, p. 60.

Swistock, B.R., Clemens, S., and Sharpe, W.E., 2009, Drinking water quality in rural Pennsylvania and the effect of management practices: Harrisburg, Pa., Center for Rural Pennsylvania, 24 p., accessed May 10, 2016, at http://www.rural.palegislature.us/drinking_water_quality. pdf.

Swistock, B.R., Sharpe, W.E., and Robillard, P.D., 1993, A survey of lead, nitrate and radon contamination of private individual water systems in Pennsylvania: Journal of Environmental Health, v. 55, no. 5, p. 6-13.

U.S. Environmental Protection Agency, 2016, Basic information about lead in drinking water, accessed April 22, 2016, at https://www.epa.gov/your-drinking-water/ basic-information-about-lead-drinking-water\#getinto. 


\section{Appendix 1. Uncertainty Associated With Estimates of Characteristic Values and Potential Effect on Classification of States}

Classification of states with respect to potential corrosivity was based on estimates of characteristic values for the states, and those estimates are subject to uncertainty. Classification with respect to the Langelier Saturation Index (LSI) was based on estimates of the average LSI for the state. The uncertainty associated with the estimate of the average LSI was computed using the standard confidence interval $\left(\mathrm{CI}_{\mathrm{s}}\right)$ at a 90-percent confidence level (Ott and Longnecker, 2001):

$$
C I_{s}=m \pm Z_{\alpha / 2} \sqrt{\sigma^{2} / n}
$$

where

$$
\begin{aligned}
& m \text { is the average value of LSI for a state, } \\
& Z_{\alpha / 2} \quad \text { is the }(1-\alpha / 2) \text { quantile of the standard } \\
& \text { normal distribution, } \\
& Z_{\alpha / 2} \quad \text { is } 1.645 \text { for a two-sided 90-percent } \\
& \text { confidence interval, } \\
& \sigma^{2} \text { is the variance of the LSI values for } \\
& \text { a state, and } \\
& n \quad \text { is the number of groundwater sites in a state. }
\end{aligned}
$$

Classification of states with respect to the Potential to Promote Galvanic Corrosion (PPGC) was based on estimates of the proportions of the sites in a state that were classified as low, moderate, or high. The uncertainty associated with estimating the proportion of groundwater sites with a given classification was computed using the Clopper-Pearson interval (Clopper and Pearson, 1934) at a 90-percent confidence level. The Clopper-Pearson interval is often referred to as the exact method. The lower bound $\left(L_{1-\alpha}\right)$ and upper bound $\left(U_{1-\alpha}\right)$ of the confidence interval were computed (Brown and others, 2001):

$$
\begin{aligned}
& L_{1-\alpha}=B^{-1}(\alpha / 2 ; k, n-k+1) \\
& U_{1-\alpha}=B^{-1}(1-\alpha / 2 ; k+1, n-k)
\end{aligned}
$$

where

$$
\begin{gathered}
B^{-1} \text { is the inverse beta distribution, } \\
k \text { is the number of successes (groundwater sites } \\
\text { with a given classification), and } \\
\text { is the total number of samples } \\
\text { (groundwater sites). }
\end{gathered}
$$

For a 90-percent confidence interval, $\alpha$ is 0.1 . If the lower bound is 0 percent or if the upper bound is 100 percent, then the interval is computed as a one-sided distribution. Brown and others (2001) have shown that the exact method is overly conservative. For example, given a nominal confidence interval of 95 percent, the average coverage probability provided by the exact method exceeds 98 percent for less than 50 samples and can approach 1.0 for less than 10 samples. The exact method was used in this report with the understanding that the computed interval provides a level of confidence somewhat greater than 90 percent.

Evaluation of the lower and upper bounds on the estimated characteristic values can be used to evaluate the sensitivity of the classification of a state to uncertainty. Given a 90-percent confidence interval, six states could be given a classification that is different from the one based on the characteristic value for the state: Kentucky, Missouri, Montana, New Hampshire, North Carolina, and Vermont.

Kentucky was classified as indeterminate with respect to LSI (fig. 2), moderate with respect to PPGC (fig. 4), and moderate prevalence with respect to the combined index (CI) (fig. 6). On the basis of the lower bound for LSI (table 3), Kentucky could be classified as potentially corrosive rather than indeterminate. On the basis of the upper bound for the proportion of groundwater sites that are classified as low PPGC (table 4), Kentucky could be classified as low PPGC rather than moderate. The classification for CI could be low or high prevalence, rather than moderate prevalence. It might also be in a class not defined in figure 5 (potentially corrosive based on LSI and low PPGC). Given these uncertainties, along with the sparse spatial coverage, the classification of Kentucky is not well constrained.

Missouri was classified as indeterminate with respect to LSI (fig. 2), moderate with respect to PPGC (fig. 4), and moderate prevalence with respect to CI (fig. 6). The classification based on LSI does not change given the upper and lower bounds on the average LSI (table 3), but the classification based on PPGC is sensitive to uncertainty. On the basis of the upper bound for the proportion of groundwater sites classified as low PPGC (table 4), Missouri could be classified as low PPGC rather than moderate PPGC. Consequently, Missouri could be classified as low prevalence rather than moderate prevalence with respect to CI. 
Montana is classified as indeterminate with respect to LSI (fig. 2), low with respect to PPGC (fig. 4), and low prevalence with respect to CI (fig. 6). On the basis of the lower bound for LSI (table 3), Montana could be classified as potentially corrosive rather than indeterminate. The classification based on PPGC does not change given the lower and upper bounds on proportions (table 4). Consequently, Montana could be in a class not defined in figure 5 (potentially corrosive based on LSI and low PPGC), rather than classified as low prevalence based on the CI.

New Hampshire was classified as potentially corrosive with respect to LSI (fig. 2), high with respect to PPGC (fig. 4), and very high prevalence with respect to CI (fig. 6). The classification based on LSI does not change given the upper and lower bounds on the average LSI (table 3), but the classification based on PPGC is sensitive to uncertainty. On the basis of the lower bound for the proportion of groundwater sites classified as high PPGC (table 4), New Hampshire could be classified as moderate PPGC rather than high PPGC. Consequently, New Hampshire could be classified as high prevalence rather than very high prevalence with respect to CI.
North Carolina was classified as potentially corrosive with respect to LSI (fig. 2), moderate with respect to PPGC (fig. 4), and high prevalence with respect to CI (fig. 6). The classification based on LSI does not change given the upper and lower bounds on the average LSI (table 3), but the classification based on PPGC is sensitive to uncertainty. On the basis of the upper bound for the proportion of groundwater sites classified as high PPGC (table 4), North Carolina could be classified as high PPGC rather than moderate PPGC. Consequently, North Carolina could be classified as very high prevalence rather than high with respect to CI.

Vermont is classified as potentially corrosive with respect to LSI (fig. 2), moderate with respect to PPGC (fig. 4), and high prevalence with respect to CI (fig. 6). On the basis of the upper bound for LSI (table 3), Vermont could be classified as indeterminate rather than potentially corrosive. The classification based on PPGC does not change given the lower and upper bounds on proportions (table 4). Consequently, Vermont could be classified as moderate prevalence rather than high prevalence with respect to CI. 
Manuscript was approved on June 22, 2016.

For additional information about this publication contact: Kenneth Belitz, Supervisory Hydrologist

U.S. Geological Survey, National Water-Quality Assessment Project 10 Bearfoot Road

Northboro, MA 01532

kbelitz@usgs.gov

Or visit the National Water-Quality Assessment Project Web site at http://water.usgs.gov/nawqa/

Prepared by the USGS Science Publishing Network, Reston Publishing Service Center 
